\title{
The Implementation of Controlling, Coaching and Counseling; for solving corruption problem in Indonesia
}

\author{
Nana Darna, Student \\ Doctoral Management Sciences of Padjadjaran University \\ Bandung, Indonesia \\ nanadarna@yahoo.co.id
}

\author{
Ati Rosliyati, Lecturers \\ Faculty of Economics, Galuh University \\ Ciamis, Indonesia \\ atyrosliyaty@gmail.com \\ Elin Herlina, Lecturers \\ Faculty of Economics, Galuh University \\ Ciamis, Indonesia \\ mrs.elinherlina@gmai.com
}

\begin{abstract}
The Implementation of Controlling, Coaching and Counseling; For solving corruption problem in Indonesia. Corruption has involved all professions in Indonesia. It has been a tradition from lower level up to the highest level of social communities. It is not only because of the condition but also degradation of moral. Building a character is not easy because it needs understanding and struggling of all the levels of Indonesian people either institutionally or morally. Corruption data in 2014 from KPK web there are 54 corruptors from all professions namely 4 legislatures, 9 head of department and ministry, 2 governors, 12 mayors, 2 echelons I, II, III, 2 Judges, 15 people from private sector and 8 people from other sector. This problem needs serious thinking to solve it, because it is not only destroying the country but also suffering the Indonesian people.

There are so many alternatives to solve the corruption in Indonesia, one of them through controlling, coaching and counseling towards someone to have corruption potentially. This case will be explained in this research and hopefully it gives a big contribution to Indonesia government in trying to destroy the corruption.

This research employed conceptual research which formulating or developing concept, framework, method, technique, logarithm or theory that representing system to solve the certain case.

The result showed that one concept has gained to prevent the corruption by using controlling, coaching and counseling continuously by the supervisor.
\end{abstract}

Keywords; Coaching, Counseling, Controlling, Corruption, Indonesia.

\section{INTRODUCTION}

Fair, wealth and human right, economic growth and the condition of democracy has damaged by regenerating corruption through all the layers of social community in Indonesia. This corruption has turn to systemic category, it means that the corruption has infected in daily life. Systemic corruption according to Ampratwum (2008:77) "Corruption pervades the entire society and in the process becomes routinized and accepted as a means of conducting everyday transactions.". Corruption in Indonesia is affected by the opportunity, motivation and the lack of control, this statement is in line with Graycar \& Sidebottom (2012:338) "Opportunities for corruption exist when there is specialised access, and when motivation and the operationality of control (or lack of operationality) are evident. Corruption is defined by Ampratwum (2008:76) "Corruption is usually defined as the transgression of formal rules governing the allocation of public resources by officials in response to offers of financial gain or political support." In the same view, corruption according to the decree of Republic of Indonesia no 28 and 31 year 1999 is an action against the law to get self wealthy or other or a corporation to steal the state wealthy.

Besides the moral support by anti-corruption, the decreasing of corruption level can also be done by controlling by the supervisor and counselor to lose the opportunity and to increase control in every activities that have an opportunity to be corrupted, although it does not guarantee to be success to overcome it. Nichols (2209:810) explain that "controlling 
corruption will require many tools; law and international law will play an important role", otherwise it can be implemented to decrease corruption in Indonesia. Graycar \& Sidebottom (2012:385) give a pessimistic comment on the success of handling infectious corruption, "It is often said that controlling corruption which has always existed and is endemic, is near enough to impossible"

\section{METHODS}

The theoretical study of controlling, directing and counselling through personal by the top layer management becoming a foundation to develop the method to solve the corruption in Indonesia. The data from website of reliable institution that is relevant to this study is used during the research. An addition of preventing corruption is focus on the implementation of controlling, coaching and counselling by the top layer directly is needed by implementing the strategy of anti-corruption.

\section{RESULTS AND DISCUSSION}

Corruption Perception Index (CPI) of Indonesia in 2014 from Transparency International Indonesia in the level of 107 and the score is 34 is left behind by Malaysia which is in level 50 by the score of 52 . There are a lot of high corruption activities in Indonesia such as: grant from government, development program, goods budgeting, misled position, and public service. The corruption of having grant is happened because of missused, data manipulation of target people and fictive data the grant receiver. The corruption in building and goods budgeting is usually happened at bribing and gratification to win the tender, cutting of the financial, decreasing the quality and quantity of materials and illegal expenditure such as social funding, security or negative funding. The miss-used of position will be profitable for the corporation; this case will happened to some who has power in either local or central government or the policy maker. Corruption in public service is on illegal funding by person or institution and bribing from the public in order to get priority service.

Since this country was founded, Indonesia has realized of the latent of corruption and keep on trying to destroy it by several strategy. There are strategy that has run according to Jasin (2015) is prevention and action. Prevention: forming national integrity, implementation of good governance and bureaucracy reformation. Action : investigation and guidance that the corruptor is wary of it. The focus of the research is to the strategy of preventing the corruption by controlling, coaching and counselling by the top manager. This is to prevent of corruption not only because of opportunity or motivation to do it but also because of lack of controlling, coaching and counselling that has been programmed by organization. The role of the top manager as a leader is needed to prevent corruption either in purpose or unknown of the staff. The top managerial can manage the staff in order that they can avoid the corruption by their work. The staff initiation without knowing the rule of the game can cause corruption, so the rule of the top managerial is important to know the rule of the game.

Hunsker (2001) in Ann \& Carr (2011:298) explain the different between coaching and counselling "Coaching is similar but not synonymous with counseling. Both of them have the same objective: to improve the employee's performance, but coaching deals with ability issues while counseling deals with personal problems." The different can be seen from the following definition: "Coaching is an activity that usually takes a dyadic form, with the coach being primarily contracted to be in service of his or her individual client." (Critchley, 2010:852). “Counseling generally addresses the employee's emotional state, the causes of personal crises and problems, and involves short term interventions designed to review problems that interfere with the employee's job performance.'(Ellinger, 2007:243).

Either coaching or counseling are implemented by the top management is to control the work of the staff to the get the goal of the organization that has been adapted by personal goal in strategic planning to avoid corruption. Moreover Bowles \& Picano (2007) argue that "the present coaching intervention was designed to provide developmental opportunities to participants who occupied middle and 
executive management positions. As an indication of coaching effectiveness, coaches rated participants' growth (over the coaching period) in terms of participants' abilities to successfully engage in behavior critical to meeting organizational goals such as scheduling activities in advance, prioritizing tasks, and utilizing existing.

An organization with high cost operational can be proxy to have corruption. An organization that has upper high cost operation is identically leak of funding. The rule of control is not only in a unit of task force but also it should be linked to their activity, this thing can be done by supervisor or the top management from the employer continuously by couching and counselling. Couching and counselling according to the act of the minister of human resource of Indonesian republic is a inherent supervising. The linked-control is not merely control by the top management but focus on the internal control system.

The decreasing of corruption is the indicator of the inherent supervising comprehensively, the result of CPI 2014 by score 34 is minus 2 score becoming 32. It means that there is a decreasing level of corruption in Indonesia in 2014 as a prestige in the implementation of inherent supervising. Inherent supervising that has a synonym with control management or internal control is any efforts to manage activities to get the goal of organization effectively, efficiently, and economically, all the sources are used and covered, data and report is reliable and the rule is obeyed.

The function of inherent supervising is useful tool for the leader of institution in doing the work based on the goal of the organization. By gaining the goal of organization effectively, efficiently, economically and well planned, the corruption will be decreasing. Whereas the meaning of internal controlling, according COSO in Paltridge\&Colbert (1994:21) is the relationship among five criteria: (1) the control environment, (2) risk assessment, (3) control activities, (4) information and communication, (5) monitoring, and the leader should make a report based on five component so it will gain the effective implementation of organization. In inherent supervising program, the success is depended on the strength if the relationship among the item of networking form, so there is no activity without inherent supervising. The factors of inherent supervising: (1) organizing, (2) Personnel management, (3) policy (4) procedure (5) recording (7) reporting (8) supervising and internal review. Organizing is a process of forming institution that has large coverage and dynamic through organization design, so it can fulfill the need and the demand of the environment development. The personnel's couching is an effort to prevent the factor of human resource that run the system and the procedure of government that has an ability professionally and morally based on their own responsibility. Policy is a guidance that has been implemented by the management to gat the goal of government. Planning is a process of stating the goal and the steps of activity that will be done in the future through any resource in achieving the goal of organization. Procedure is a systematic action to do the activity to get the goal. Recording is a process of documentation of transaction or event systematically that is relevant with the organization. Recording includes process of data management to get the information in the form of report. Reporting is a form of sharing information in the form writing to the higher unit or other institution that has relationship with the institution. Reporting is a logic consequence from the policy delegation. Physically, reporting can be in a form of letter or other media. Supervising is a control of top management toward the work of their employee. Internal review is an activity done by the leader together with the staff or by the government internal supervisor. In other words, internal review is to check the control system to convince the goal of organization.

\section{CONCLUSIONS}

The infected corruption in the daily life of society can only be destroy by integrating all the methods and commitment of the whole component of the society to avoid the statement of systemic corruption. There are two categories to destroy corruption namely action and prevention. Controlling, 
coaching and counselling is a pattern of internal control in preventing corruption that hopefully the work of organization is run effectively, efficiently, economically and well-planned. By optimal inherent supervising of Indonesian government, thus the corruption will be disappeared or decreased.

The work pattern of government priority or public priority rather than self priority should be a philosophy of the Indonesia. So the crime toward the country will be disappeared. The pattern of internal control or inherent supervising as an asset to control each other and give warning to the co-worker, the top management forbid any kind of activity against the law, to get self wealthy, other and corporation.

\section{REFERENCES}

Aldridge, C Richard \&Colbert, Janet L. (1994). Management's report on internal control, and the accountant's response. Managerial Auditing Journal; 1994; 9, 7; Accounting \& Taxpg. 21

Ampratwum, Edward Fokuoh. (2008). The Fight Against Corruption and its Implications for Development in Developing and Transition Economies. Journal of Money Laundering Control. Vol. 11 No. 1, 2008 pp. 76-87 Emerald Group Publishing Limited 1368-5201.

Ann, Cheryl \& Carr, Adrian N. (2011).Inside outside leadership. development: coaching and storytelling potential. Journal of Management Development. Vol. 30 No. 3, 2011 pp. 297-310. Emerald Group Publishing Limited 0262-1711.

Bowles, Stephen \& Picano James. (2007). Coaching leaders in middle and executive management: goals, performance, buy-in Leadership \& Organization Development. Journal Vol. 28 No. 5, 2007 pp. 388408 Emerald Group Publishing Limited. 0143-7739

Critchley, Bill. (2010)Relational Coaching: Taking the Coaching High Road. Journal of Management Development Vol. 29 No. 10, 2010 pp. 851-863 Emerald Group Publishing Limited 0262-1711.

Ellinger, Andrea D. et al. (2007).Behavioural indicators of ineffective managerial coaching A cross-national study. Journal of European Industrial Training Vol. 32 No. 4, 2008 pp. 240-257. Emerald Group Publishing Limited 0309-0590
Graycar, Adam \& Sidebottom, Aiden. (2012). Corruption and control: a corruption reduction approach. Journal of Financial Crime Vol. 19 No. 4, 2012. pp. 384-399. Emerald Group Publishing Limited 1359-0790.

Jasin, Mochammad. (2015).Pola Pemberantasan Korupsi Sistemik Melalui Pencegahan dan Penindakan. Sekretariat Negara Republik Indonesia.http://www.setneg.go.id/.

Nichols, Philip M. (2009). Multiple Communities and Controlling Corruption. Journal of Business Ethics (2009) 88:805-813. Springer 2009.

Web Site:

http://www.ti.or.id

http://acch.kpk.go.id

Keputusan Menteri:

Keputusan Menteri Pendayagunaan Aparatur NegaraNomor: KEP/46/M.PAN/4/2004 Tentang Petunjuk Pelaksanaan

Pengawasan Melekat dalam Penyelenggaraan Pemerintahan.

\section{ACKNOWLEDGEMENTS}

Thanks God for His mercy and help, this journal is finished. Thanks for Prof. Dr. Hj. Erni Tisnawati Sule, SE., M.Si. as the head of Doctoral Program of Management Science and all the lecturers and staffs in Padjadjaran University, Dr. H. Yat Rospia Brata, M.Si. as Rector and all the lecturers and staffs Galuh University. 